Special issue: Re-Design Teaching Design

Article

\section{Design Pedagogy: The New Architectural Studio and Its Consequences}

Peggy Deamer

Professor Emerita, Yale School of Architecture, Yale University, USA; peggy.deamer@yale.edu

Guest Editors: Lohren Deeg, Taylor Metz, Richard Tursky, Ball State University, USA

How to Cite: Deamer, P. 'Design Pedagogy: The New Architectural Studio and Its Consequences'. Architecture_MPS 18, 1 (2020): 2. DOI: https://doi.org/10.14324/111.444.amps.2020v18i1.002.

Submission date: 31 March 2020; Acceptance date: 12 June 2020; Publication date: 1 September 2020

\section{Peer review:}

This article has been peer-reviewed through the journal's standard double-blind peer review, where both the reviewers and authors are anonymised during review.

\section{Copyright:}

(c) 2020, Peggy Deamer. This is an Open Access article distributed under the terms of the Creative Commons Attribution Licence (CC BY) 4.0 https://creativecommons.org/licenses/by/4.0/, which permits unrestricted use, distribution and reproduction in any medium, provided the original author and source are credited $\bullet$ DOI: https://doi.org/10.14324/111.444.amps.2020v18i1.002.

\section{Open Access:}

Architecture_MPS is a peer-reviewed Open Access journal.

\begin{abstract}
This article argues that the typical architectural studio is both outmoded and irresponsible. It is outmoded because it typically is organized around a nineteenth-century model of design virtuosity, and it is irresponsible because it ignores pressing and current spatial justice problems. It also takes to task the aura of the academic setting in which the formally motivated studio reigns supreme. In lieu of this model of architectural education, the article argues for an education that empowers graduates to tackle the major problems that society currently faces: housing, climate, income inequality/unemployment and health. To do this, it acknowledges but suggests overthrowing the many institutional hurdles keeping architectural education attached to the status quo.
\end{abstract}

Keywords: architectural studios; the academy; formalism; professionalism; architectural design; architectural theory; professional practice 


\section{Introduction}

The year 2020 presents us with four big problems: housing, climate, income inequality/unemployment and (now) health. ${ }^{1}$ The litmus test for our architectural profession is its ability to address these issues; the test for architectural schools is their ability to produce citizens who can operate in such a profession; and the test for an architectural design studio is its ability to draw the connection between design and the rhizomatic world in which it operates. Working negatively in the other direction, the failure of a studio to engage with the world is linked to a school's failure to prepare an architect empowered professionally to serve society.

This article will postulate a studio pedagogy that can live up to its obligation to produce an effective architectural citizen and, from that, suggest a new role for architectural academia. The goal is to move beyond our current nineteenth-century, Beaux-Arts modelled system of design education and dispense with the charrettes, the competition, the design virtuosity, the heroic programmes and the honouring of past masters who characterize it. Even in unproblematic times, change is overdue; today it is urgent.

There are so many ironies associated with our attachment to the nineteenth-century model. The first is that the Beaux-Arts tradition was so remarkable because it reflected its era. Durand's system of compositional gridding was a strategy for handling unprecedented and newly complex building programmes; the Grand Prix-dominated pedagogy conformed to an era of governmental patronage; and Viollet-le-Duc's structural rationalism responded to the new materials and the construction trades introduced by industrialization. And as Magali Sarfatti Larson has indicated, the professionalization of the architect that the education was tied into was particular to early liberal capitalism's need to establish an elite knowledge sector centred on ideals of noblesse oblige, standardization, and a progressive division of labour - all things that no longer warrant support.

The second is that the modernist masters whom we revere never had such schooling. Le Corbusier worked under his father, a Chaux-de-Fonds watchmaker, and was tutored by Charles l'Éplattenier, a Swiss Art Nouveau painter and architect whom Le Corbusier claimed taught him everything he needed to know. Ludwig Mies van der Rohe worked in his father's stone-carving shop and at several local design firms before joining the office of interior designer Bruno Paul and later apprenticing at the studio of Peter Behrens. Walter Gropius studied at technical schools, first in Munich and then Berlin, but he dropped out without taking the final exam, reflecting an early disregard for traditional methods of education. Frank Lloyd Wright studied civil engineering as a special student at the University of Wisconsin (leaving without a degree); worked for Allan D. Conover, a professor of civil engineering; and was hired as a draftsman with the architectural firm of Joseph Lyman Silsbee, participating in the construction supervision of his father's Unity Chapel in Spring Green. Buckminster Fuller, while attending (and being kicked out of) Harvard, did not study architecture and was trained as a machinist.

The third is that we miss the fundamental lesson of a Beaux-Arts master, Tony Garnier, who won the Prix de Rome in 1899 for designing a national bank, not his Cité Industrielle for which he is known. The point is, the project that won kudos in the Beaux-Arts prize system/pedagogy (the bank) had nothing to do with the project to which he devoted his life. The school demanded an object; he wanted to solve a problem. The spatial visions he produced in Cité Industrielle included the zoning of activities for health and fresh air, the consideration of passive energy, the greening of the city, and the concern for wind and water distribution. These goals were matched by his social concepts, such as dispensing with private property, the elimination of prisons, barracks, courts or walls (since citizens would have no need to misbehave), and the elimination of churches. But of all these lessons, the most relevant for studio teaching today is that Garnier was not interested in objects; he was interested in the entire system relevant to early-twentieth-century urbanism: the role that industrial production would play in cities and regional natural catchments.

With Garnier's Cité Industrielle in mind, we can look at transformations in studio teaching and, from that, the architectural academy in which it operates. 


\section{Studio}

Many assumptions go along with our Beaux-Arts approach to studio education: the primacy of representational virtuosity; the generic, benign, Western culture programmes; the limiting of external realities for impinging on creativity; the absence of experts other than architects; the striving for graduation awards that will launch a European tour; the designing of an object. In lieu of these tropes that incite what surely is false consciousness, studios should interrogate present-day problems to rehearse a positive future. When we no longer think of design as equal to form-making and studio as the location of object formation, three axes that expand our notion of design can shape studio pedagogy (Figure 1).

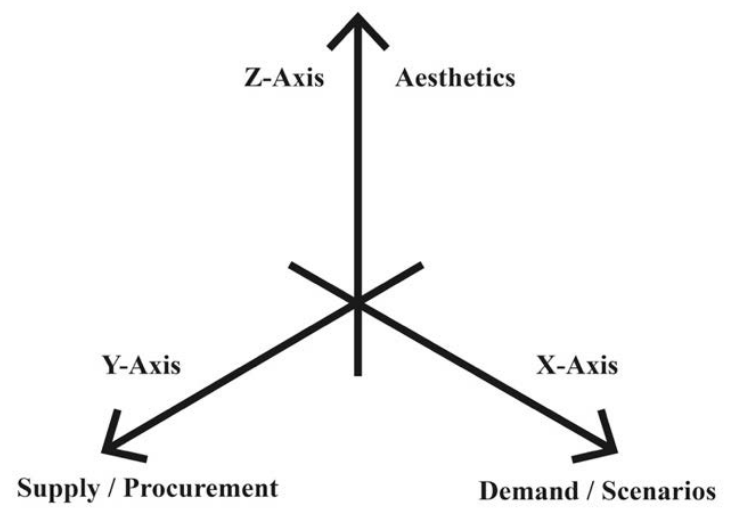

Figure 1 The three directions that shape studio pedagogy (Source: Lohren Deeg, 2020).

\section{X-Axis: Demand/Scenarios}

We need to place in the foreground the demand context for our acts, where demand implies both the implicit demands of our society and the demand for people to find their places in the world. In other words, we need to design, in lieu of objects, scenarios for people to interact. Garnier did not invent the society he housed in the Cité Industrielle; he received directions from the mayor of Lyon as to what was needed politically, socially and environmentally in the region. In emphasizing scenarios over objects, priorities change. We educators are forced to confront our own preconceptions. We think more about the identity of occupants who will experience the spaces we have made for them. We begin to consider the institutional powers that create those identities. We understand the temporal flux of the scenario and think about change over time. We no longer imagine our solutions to operate within a discourse of commodification and cultural consumption. We realize we are not the only agents determining the shaping of the scenario - politicians, developers, community leaders, eventual users, environmentalists and economists play parts - but we are, because we are on the ground, the bridge between those we hope to serve and the spatial and institutional systems in which they live. This is the $\mathrm{X}$-axis of studio design.

\section{Y-Axis: Supply/Procurement}

The Y-axis of studio design is the supply side of that scenario, the procurement process. Garnier identified all the new materials, steel and concrete specifically that the Cité would be built with, as well as how they could be sourced; he wanted to make sure his scenario could realistically be delivered. For our scenarios, students need to consider who builds, with what materials, coming from where and by what means. What suppliers, fabricators and labourers are set in motion in an effort to be more sustainably aware?

Designing the procurement process today comes with implications. One is embracing the software and apps that allow access to expanded and relevant information and invite - or rather, insist on collaboration with other industries. Another implication is bringing experts from the construction industry into the studio, a readjustment of architects' assumed design hegemony at the top of the architecture, engineering and construction industry, and the class prejudices that come with it. Another is the joint, collaborative research necessary for students to grasp the supply chain pertinent to their projects. And yet 
another implication is consciousness of the labour within the design process itself: how are design decisions being made, in what context, under what time constraints and for whose gain? In other words, what implicit or explicit rules are being imposed about student labour, and what do these imply for assumed models of success?

\section{Z-Axis: Aesthetics}

Aesthetics constitute the Z-axis of design pedagogy: form and visual representation are the language architects speak, and the design studio must speak it well. Garnier was only recognized at the school because of his evident formal skills, and today we pay attention to Garnier's work because it is, if nothing else, beautiful.

Formal thinking begins with abstraction. Regardless of actors and materials, spaces, elements and walls constitute their own relational dance without reference to function, type or material. Proportion, plane/volume, solid/void, big/small, twisted/straight, repetitious/distinct, etc. - these are fundamental relationships that need to be mastered. But when they are sensually animated - rough/smooth, light/dark, soft/hard - the abstraction becomes more specific. And when the construction logic is decided trabeated/bearing wall/exoskeleton, wood/steel/concrete, muted or articulated joints - a certain labour force is implicated. Further still, when the design is seen through the eyes of various subjectivities - feminine/masculine, bourgeoise/ascetic, historically referential/mute, western/eastern, etc. - the socio-political relationships are not neutral; they are necessarily motivated.

In all of this, the fundamentals of form, I believe, should be taught individually and early. While studios need to embrace collaboration and the sharing of knowledge as they progress, the starting point must give each student confidence in their formal ability. In studios I have run, I regularly ask students to exchange their solutions for a given period (one studio session or half a week) with another student so that a fresh pair of eyes can review the proposed design. This inevitably reveals the self-imposed restrictions each student has put on their design thinking and reveals either new spatial solutions or alternate ways of understanding a concept. The student who began the project can either accept the rethinking or not, but usually no student is silly enough to reject a better idea merely because it is not their own, and most recognize that this is how design will work in an office. The exercise does not make design a group activity; it simply offers group intelligence to an individual project.

Representational techniques, related to spatial form but different, must also be learned. If the world sees only a fraction of the spaces we design, it sees oceans of our drawings, charts, maps and diagrams. Like form, it requires abstract thinking: information must be understood hierarchically. But it, too, is quickly instrumentalized, and a student needs to learn how to control its consumption. On the one side, this relates to the author's identity (what aesthetic is desired) and on the other, how, where and by whom it will be received.

I fear these directives are based on adjustments to existing norms and not on radically new approaches to aesthetic pedagogy, but the directives have embedded in them procedural assumptions that are less debatable. First, that the results of a studio should not be judged by a be-all-and-end-all jury that only considers the formal virtuosity of the student work, but rather that the jury should also discuss the depth with which the issues impinging on design solutions have been taken into consideration. Second, that by the time one reaches an upper-level studio, neither student nor critic is talking about form divorced from the scenario it participates in or the process by which procurement is articulated. And third, that the health of the student, and not the valour of the critic to incite passion (and all-nighters), is prioritized.

\section{Architectural Academia}

Studio does not work in a vacuum. It functions in the larger system of architectural academia. And like the ideology of traditional studios, architectural education operates within tropes meant to preserve its supposed creative specialness. Just as we have traditionally thought the studio to be free of conditions that impinge on creativity, we see the university as an ideal bubble divorced from what came before (too intellectually naive, too saturated with the quotidian) or will come after (too limited in an instrumentalized profession). This view of academia as the ideal middle - uncompromised, speculative, 
utopian - supports a view of architectural education that is untainted by real-world constraints. In particular, as the architectural academy tries to distinguish itself from previous knowledge experiences and future professionalism, architecture schools take on the mantle of formal sovereignty. Why this is the case, especially in an era that so needs our spatial, on-the-ground, and organizational expertise, can only be speculated on, but it seems that modernism still has us unproductively in its grip.

While architects strive to be as radical, socially powerful and formally innovative as the work achieved in the 1930s, while also getting to grips with its social failures and aesthetic marginalization, the academy constructs new forms of supposed success - all variations on stylistic and representational schemas. Ironically, this lands us in the safe haven of Beaux-Arts pedagogy, missing the basic 1930s turn away from standard bourgeoise programmes and academicized aesthetic prescriptions. Regardless, even if this explanation is wrong, the fact of being stuck in the nineteenth-century model is illogical and its consequences sad.

As schools brand themselves as the singular location of formal play and ingenuity, they compete for students based primarily on their studio pedagogy. Design studios carry three times as many points as other courses. The entire curriculum sequence of, say, a three-year master's programme is organized around the studio sequence. Faculty teaching ancillary courses other than structures and required history lecture courses are hired primarily for their design skills and then (if they are lucky) given seminars that are generally labelled theory but examine instead formal proclivities. Ancillary courses are asked to adjust their semester workload so as to not interfere with studio deadlines. When the architecture student very quickly learns that sacrificing attention to non-design courses is forgiven if their aesthetic work is attention-getting, and that garnering kudos from both fellow students and the faculty rests on design output, it is not from assessing a covert message but from correctly reading the school's overt mission.

In lieu of concentrating on the essential meaning of architecture and the preservation of its design sovereignty, architecture schools should be think-tanks, not only bringing together the above-listed theory and ancillary courses in tandem with studio, but also taking on issues of spatial justice that the formal agenda overlooks. Right now, extra-academic associations - e-flux, Archinect, the Architecture Lobby, ArchiteXX, NOMA, Terreforme, Architects/Designers/Planners for Social Responsibility (ASPSR), Aggregate, the McHarg Center, the Buell Center (not to mention activist organizations outside architecture) - bear the burden of addressing our contemporary problems and preparing students to confront them. How frustrating that these organizations, using volunteer labour and operating with little money, do the job that the rich and well-resourced academies should be doing.

If schools of architecture were willing to take on this think-tank role, changes in intellectual content and administration would obviously need to occur on various levels.

\section{Curricula Content}

Course content across the board should change. The design curriculum, discussed above, need not be repeated here, but it is clear that in calling for an infiltration of non-studio material into the studio, the material and delivery of these other courses changes as much as its content.

Theory comes to the fore. If history has dominated our past 20 years of history/theory as it avoids criticality and hides in the safety of archives, theory now matters more than ever. Already responsible for drawing whatever connection we have between studio and colonialism, Eurocentrism, racism, and gender inequity, theory now moves to other urgent realms. In this regard, e-Flux's series Theory's Curriculum is a model for a new pedagogical content. ${ }^{2}$ Gathering together proposed theory syllabi, the series revels in moving away from traditional thematic categories and organizing content around themes such as property, labour, the particular, the universal, alienation and bodies.

Technologies that make us more intelligent and collaborative, and mechanisms that break down the difference between design, construction and resource evaluation, should be embraced. It is not the case that technology distances us from the real, personal engagement with form; rather, it facilitates access to the conditions that contextualize and expand design. Technology is never a threat to good work unless it is wrongly understood and deployed. Building Information Modelling (BIM), properly taught, takes modelling out of an efficiency-based discourse and into the inefficient but empowering 
realm of collaboration and knowledge sharing. Coding is essential for students who want to lead and not follow programming directives. Artificial intelligence, virtual reality and augmented reality, when housed in the humanist architectural context, can offer democratic access to decision making. Systems thinking is a must. At the same time, enthusiasm for technical connectivity must be matched by scepticism about techno-utopianism. Automation threatens jobs and is generally pursued for the sake of so-called progress without concern for what society actually needs. Job displacement is a problem that requires more specific answers than universal basic income, since we do not just want more money, we also want meaningful work.

Structures and environmental systems, besides being brought into the studio, emphasize their historical evolution, cultural deployment and evolving experimentation. Like the abstraction at the base of formal thinking, there are indeed acultural, abstract formulas that need to be taught. But these, too, should quickly get contextualized. For example, Edward Ford's The Details of Modern Architecture places construction in a historical framework, and Daniel Barber's A House in the Sun does the same with environmental systems. ${ }^{3}$ In showing that our seemingly empirical constructs are indeed culturally motivated, students will learn how to construct differently, or, at least, consciously.

Professional practice courses, traditionally the hinge between academic speculation and the (seemingly limiting) real world, should disappear. In one sense, all years and most of the courses within a year are professional practice in the sense of practising what our métier offers. In another, none of them are strictly professional in that learning about normative contracts, responsibilities, business plans, liability and licensure, is no longer our preferred horizon; changing them in order to change our relationship to power is.

\section{Administration}

The current categorization of curricular area domains is only good for administrative clarity; it is bad for flexibility and relevance. If we prioritize students' needs instead of institutional efficiency, we would have a stronger army of researchers. In lieu of the area fiefdoms of design, structures and history/theory, etc., under which most courses are managed, courses could be referenced according to the knowledge threads the school foregrounds. Finance, activism, climate change, housing, immigration, construction, aesthetics, globalism, race/gender/identity, fashion, cultural hegemony, industrialization, modernism, infrastructure, landscape, medium, the human/post-human, and politics are possible topics around which faculty from different areas of expertise could cluster.

For the students' sake, the school can list the courses falling into a given knowledge thread, so students do not need to read between the lines of a catalogue to identify courses and instructors supporting their interests. For the faculty's sake, those engaged in similar threads, regardless of being historians or techies or designers, can share their syllabi (probably for the first time) and develop complementary approaches to the thread. To cover more intellectual material and provide more opportunities for cross-fertilization, semesters/quarters could be subdivided, making the material in each course shorter, less pedantic and more focused. Knowledge dispersal would be passed from one instructor to another.

Inevitably, academic institutions would struggle with this rhizomatic approach to delivering education. Traditional scheduling, hiring and course-load distribution go out the window, as do easy criteria for assessing student progress and competency. It seems obvious, though, that students would participate in the administrative conditions, that courses would be pass-fail, awards would be dispensed with, and a final project (thesis) would provide proof of intellectual and design tenacity.

The bigger question, however, is how each school covers the vast array of material that constitutes relevance within a three-year programme. My thinking is: we spread the work. We identify schools not according to the style of architecture they produce and/or which stars they have on staff, but by the area of expertise each is capable of taking on, given its location and larger university context. For example, Yale has access to its famous law school; Georgia Institute of Technology has access to extraordinary technological facilities; and Berkeley has access to Stanford and IT heaven. The goal is not silo-making but rather organizing areas of intelligence to complement each other in lieu of competing with each other. ${ }^{4}$ 
How does this work in our current accreditation and licensing system? It does not, so the National Architectural Accreditation Board (NAAB) would need to adjust. Its new role might consist of ensuring that each individual school's advertised knowledge threads are adhered to and properly populated; and, across schools, make sure no school protects its own explorations or ignores the larger social research agenda it is mandated to protect. If NAAB could accredit in such a manner, still the National Council of Architectural Registration Boards (NCARB) would probably protest. Unable to properly categorize, evaluate and standardize licensure, it, too, would baulk. This would be ironic since it is the role of state licensing boards to ensure public welfare; yet the limited understanding of architecture as building and not spatial justice actually prevents architects from serving the public.

We can suggest a system of progressive licensure that allows architects to work on different types and scales of projects based on their education and experience. Such an approach is currently being discussed by the New Zealand Institute of Architects (NZIA). Or one could follow the Swedish example of not licensing architects. In lieu of monitoring who does and does not deserve the title of architect, the Swedes monitor whether schools and practices stay up to date on sustainable methods of procurement and public access to real estate. In other words, the Association of Swedish Architects emphasizes knowledge, not skills nor the preservation of its specialness. If these new approaches to professionalization fail, we could just refuse to play by the rules and never register, happily giving up the privilege of signing drawings for work that is probably of interest only to developers.

\section{Conclusion}

At a post-conference meeting of speakers at the McHarg Center's Designing the Green New Deal on 14 September 2019 - participants included Naomi Klein, Jane McAlevey, Raj Patel, Rhiana Gunn-Wright and Varshini Prakash (of the sunrise movement) - architectural academia was identified as a major stumbling block for marshalling design attention to the Green New Deal. Indeed, the conference at the University of Pennsylvania the day before, despite being held near the School of Architecture, had neither an architecture student nor faculty member in attendance. Likewise, at the RISD (Rhode Island School of Design)-sponsored Climate Futures 2: Design Politics and the Green New Deal on 5 December 2019, no architecture students could be seen, and only one faculty member was in attendance (and only for one-quarter of the day). As the most visible of the four problems that 2020 has handed us, the absence of participating architectural academics in events like these is deeply disturbing.

The proposals made by this article began with the call to move away from a nineteenth-century model of architectural education to one that is relevant for today. In doing so, it has offered suggestions that are increasingly implausible in our current, deeply conservative profession and the neoliberal era in which it operates. The hope, however, is that some of the ideas can be followed, even if not to an institution-wrecking extent. At the same time, the call for relevance and its awkward consequences need not be seen as permanent. This article is not a call for a universal, idealized architectural education; it is time-specific. Whether we call the period we are in an exceptional crisis or an extension of policies that make Covid-19 and climate failure inevitable, these challenges require a swerve in how we prepare architects and designers to contribute to spatial and social justice. We desperately need to get unstuck and mobilize for the present. If our profession and its schools come out of this health and climate crisis even partially intact, we can then hopefully reassess.

\section{Declarations and Conflict of Interests}

The author declares no conflict of interests with this work.

\section{Notes}

${ }^{1}$ At the time of writing, Covid-19 is keeping all of us in isolation.

${ }^{2}$ Axel et al., 'e-flux architecture'.

${ }^{3}$ Ford, Details of Modern Architecture, vols 1 and 2; Barber, A House in the Sun; see also Barber, Modern Architecture and Climate. 
${ }^{4}$ Attending the Intelligent Environments and Entrepreneurship conference at Georgia Tech's School of Architecture, 25-26 October 2018, made me acutely aware of the fact that, as a school, Georgia Tech could test technology in a way that Yale School of Architecture, for example, never could. Conversely, technology, there, was absent in discourse of social or human relevance, something that we were teaching at Yale. These concerns clearly needed to be thought together, but not in equal measure in both places.

\section{References}

Axel, Nick, Joseph Bedford, and Nikolaus Hirsch, eds. 'e-flux architecture - Theory's Curriculum'. Accessed 23 July 2020. https://www.e-flux.com/architecture/curriculum/.

Barber, Daniel A. A House in the Sun: Modern Architecture and Solar Energy in the Cold War. Oxford: Oxford University Press, 2016.

Barber, Daniel A. Modern Architecture and Climate: Design before Airconditioning. Princeton, NJ: Princeton University Press, 2020.

Ford, Edward R. The Details of Modern Architecture, vols 1 and 2. Boston, MA: MIT Press, 1997.

Sarfatti-Larson, Magali. The Rise of Professionalism: A Sociological Analysis. Berkeley: University of California Press, 1977. 